\title{
Analisis Dampak Pembangunan Pelabuhan Terhadap Biaya Transportasi : Studi Kasus Pelabuhan Teluk Prigi di Wilayah Jawa Timur
}

\author{
Norma Syahnasa Diah Islami, Christino Boyke S.P dan Ferdhi Zulkarnaen. \\ Departemen Teknik Transportasi Laut, Fakultas Teknologi Kelautan, Institut Teknologi Sepuluh \\ Nopember (ITS) \\ e-mail: ferdhi.zulkarnaen@gmail.com
}

\begin{abstract}
Abstrak-Pemerintah mewacanakan pembangunan Pelabuhan Teluk Prigi sebagai pelabuhan komersil untuk menunjang perekonomian di selatan Jawa Timur, terutama untuk aktivitas bongkar muat barang general cargo, curah dan penumpang . Penelitian ini menggunakan perbandingan biaya transportasi dengan rute melalui pelabuhan Tanjung Perak dan rute melalui Pelabuhan Teluk Prigi menggunakan perhitungan biaya transportasi dan inventory carrying cost. Moda transportasi yang digunakan adalah truk engkel sebagai moda transportasi darat dan kapal general cargo untuk moda transportasi laut. Hinterland dari pelabuhan Teluk Prigi yang terpilih adalah kabupaten Magetan, Ponorogo, Nganjuk, Blitar, Tulungagung, Kediri, Trenggalek dan Pacitan. Hasil dari penelitian ini menunjukkan bahwa perbandingan biaya transportasi dan inventory carrying cost secara keseluruhan dari hinterland dengan tujuan Jakarta, Kalimantan Selatan, Bali, dan NTT lebih rendah jika dikirimkan melalui Pelabuhan Tanjung Perak. Selisih unit cost biaya transportasi sebesar Rp. 5.375 per ton untuk tujuan Jakarta, . 9.284,- per ton untuk muatan tujuan Kalimantan, Rp. 1.475,- per ton untuk muatan tujuan Bali dan Rp. 2.846,- per ton untuk muatan tujuan NTT.
\end{abstract}

Kata kunci-Pelabuhan Tanjung Perak, Pelabuhan Teluk Prigi, Biaya Transportasi, Inventory Carrying Cost.

\section{PENDAHULUAN}

$\mathrm{P}_{\mathrm{p}}$ ROVINSI Jawa Timur merupakan tolok ukur perekonomian nasional setelah DKI Jakarta dan Provinsi Jawa Barat, sebab kontribusi PDRB Provinsi Jawa Timur terhadap Produk Domestik Bruto (PDB) nasional mencapai sekitar 16 persen [1]. Provinsi Jawa Timur mengalami kesenjangan pada perekonomian daerah terutama pada daerah-daerah kabupaten di wilayah selatan. Hal tersebut dapat dilihat pada nilai Pendapatan Domestik Regional Bruto (PDRB) daerah, konsentrasi kegiatan perekonomian di daerah Jawa Timur utara sebesar $85 \%$ jauh meninggalkan daerah Jawa Timur selatan [2].

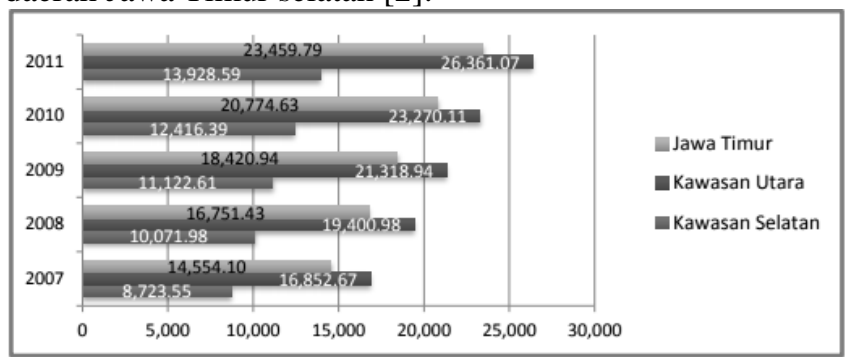

Gambar 1. Perbandingan Pendapatan Perkapita Provinsi Jawa Timur
Kesenjangan perekonomian salah satunya disebabkan oleh sebaran daerah industri dan aksesbilitas pengiriman barang. Barang dari wilayah Jawa Timur selatan harus diangkut melewati jalur darat yang jaraknya cukup jauh menuju pelabuhan Tanjung Perak Surabaya. Rantai pengiriman barang yang panjang mengakibatkan kualitas barang menurun sehingga barang menjadi kurang kompetitif dan kalah bersaing di pasaran. Oleh karena itu, pemerintah provinsi Jawa Timur mewacanakan pembangunan pelabuhan Teluk Prigi yang terletak di Teluk Prigi, kabupaten Trenggalek sebagai pelabuhan komersil yang melayani bongkar muat barang general cargo, curah kering dan penumpang. Selain itu, seiring dengan pembangunan Jalur Lintas Selatan (JLS) pelabuhan Teluk Prigi mampu menjadi titik tumpu arus distribusi logistik dari wilayah koridor Jawa Timur selatan hingga menuju daerah lain di Indonesia. Efek dari pembangunan pelabuhan komersil tersebut diharapkan mampu mendongkrak kemajuan sektor perekonomian dan pariwisata pesisir di daerah Trenggalek. Dalam Studi ini dilakukan perhitungan biaya transportasi dan inventory carrying cost pelabuhan Tanjung Perak Surabaya dan Pelabuhan Teluk Prigi kemudian dianalisis perbandingan biayanya.

\section{KONSEP DAN URAIAN PENELITIAN}

\section{A. Konsep Biaya Transportasi Laut}

Pada umumnya biaya transportasi laut terbagi kedalam empat kategori utama yaitu biaya modal (capital cost), biaya operasional (operational cost), biaya pelayaran (voyage cost), dan biaya bongkar muat (cargo handling cost) [3]. Berikut ini penjelasan lebih lanjut pada biaya transportasi laut:

\section{a. Biaya Modal (Capital Cost)}

Capital Cost adalah harga kapal pada saat dibeli atau dibangun. Biaya modal disertakan dalam kalkulasi biaya untuk menutup pembayaran bunga pinjaman dan pengembalian modal tergantung bagaimana pengadaan kapal tersebut. Pengembalian nilai capital ini direfleksikan sebagai pembayaran tahunan.

b. Biaya Operasional (Operational Cost)

Operating Cost adalah biaya-biaya tetap yang dikeluarkan untuk aspek-aspek operasional sehari-hari untuk membuat kapal selalu dalam keadaan siap berlayar. Operating Cost terdiri dari biaya perawatan dan perbaikan, gaji ABK, biaya perbekalan, minyak pelumas, asuransi dan administrasi. 
$O C=M+S T+M N+I+A D$

Keterangan:

$\mathrm{OC}=$ Operating Cost

$\mathrm{M}=$ Manning

ST =Stores

$\mathrm{MN}=$ Maintenance and repair

I =Insurance

$\mathrm{AD}=$ Administration

1) Manning Cost

Manning cost adalah biaya yang dikeluarkan untuk gaji termasuk didalamnya adalah gaji pokok, tunjangan, asuransi sosial, dan uang pensiun kepada anak buah kapal atau biasa disebut crew cost.

2) Store Cost, supplies and lubricating cost

Jenis biaya pada kategori ini terbagi dalam tiga macam, yaitu marinestores (cat, tali, besi), engine room stores (spare part, lubricating oils), dan steward's stores (bahan makanan).

3) Maintenance and repair cost

Merupakan biaya perawatan dan perbaikan mencakup semua kebutuhan untuk mempertahankan kondisi kapal sesuai dengan standar kebijakan perusahaan maupun persyaratan badan klasifikasi, biaya ini terbagi menjadi tiga kategori, yakni survey klasifikasi, perawatan rutin dan berbaikan.

4) Biaya Asuransi (Insurance)

Merupakan biaya asuransi yaitu komponen pembiayaan yang dikeluarkan sehubungan dengan risiko pelayaran yang dilimpahkan kepada perusahaan asuransi.

5) Biaya Administrasi (Administration)

Biaya administrasi diantaranya adalah biaya pengurusan surat-surat kapal, sertifikat dan pengurusannya, biaya pengurusan ijin kepelabuhanan maupun fungsi administratif lainnya.

c. Biaya Pelayaran (Voyage Cost)

Biaya pelayaran atau voyage cost adalah variabel yang dikeluarkan oleh kapal untuk kebutuhan selama pelayaran. Komponen biaya pelayaran adalah:

$V C=F C+P D+T P$

Keterangan:

$\mathrm{VC}=$ Voyage Cost

$\mathrm{FC}=$ Fuel Cost

$\mathrm{PD}=$ Port Dues atau ongkos pelabuhan

$\mathrm{TP}=$ Pandu dan tunda

1) Biaya Bahan Bakar

Biaya bahan bakar tergantung pada konsumsi harian bahan bakar selama berlayar di laut dan di pelabuhan serta harga bahan bakar [4]. Jenis bahan bakar yang dipakai ada 3 macam yaitu HSD, MDO, dan MFO.

2) Biaya Pelabuhan

Biaya pelabuhan meliputi port dues dan service charges. Port dues adalah biaya yang dikenakan atas penggunaan fasilitas pelabuhan berupa fasilitas dermaga, tambatan, kolam labuh, dan infrastruktur lainnya yang besarnya tergantung volume cargo, berat cargo, gross tonnage dan net tonnage. Service charge meliputi jasa yang dipakai kapal selama dipelabuhan termasuk pandu tunda. d. Biaya Bongkar Muat ( Cargo Handling Cost)

Biaya bongkar muat (Cargo Handling Cost) adalah biaya untuk proses pemindahan muatan dari kapal ke pelabuhan baik di pelabuhan asal ataupun pelabuhan tujuan. Biaya ini dipengaruhi oleh jenis muatan, design kapal dan alat bongkar muat yang digunakan.Biaya ini meliputi biaya Stvedoring, cargodoring.

\section{B. Konsep Biaya Transportasi Darat}

Saat ini belum ada standar baku yang dapat dijadikan acuan semua pihak dalam menentukan standar kenaikan atau penurunan biaya darat. Berikut merupakan beberapa metode yang digunakan untuk menentukan biaya transportasi truk sebagai berikut:

\section{1) Metode Riil Cost/Back to Back Cost}

Metode riil cost/back to back cost merupakan metode yang dipakai dan disepakati antara principle/customer dengan transporternya yang menggunakan selisih kenaikan atau penurunan harga BBM terhadap tarif angkutan. Berikut rumus metode riil cost adalah sebagai berikut:

Rasio BBM : 1 : 3 (1 Liter untuk 3 Km)

$$
\begin{array}{r}
C_{B B M}=P_{B B M} x \text { Cons }_{B B M} \\
\text { Rasio }=\frac{C_{B B M}}{\text { Tarif Sewa Truk }}
\end{array}
$$

Keterangan:

$\begin{array}{ll}\mathrm{C}_{\mathrm{BBM}} & =\text { Biaya BBM } \\ \mathrm{P}_{\mathrm{BBM}} & =\text { Harga BBM } \\ \text { Cons }_{\mathrm{BBM}} & =\text { Konsumsi BBM }\end{array}$

2) Metode Persen Biaya BBM terhadap Tarif

Metode \% biaya BBM terhadap tarif merupakan metode yang dipakai dan disepakati antara principle/customer dengan transporternya dengan menggunakan \% $\mathrm{BBM}$ terhadap tarif angkutan. Dalam metode ini disepakati terlebih dahulu persen BBM terhadap tarif, apakah $25 \%$, $30 \%$ atau $35 \%$. \% BBM dikalikan dengan tarif, maka didapatlah estimasi biaya BBM dibagi dengan rasio BBM truk, maka akan diketahui jumlah liter yang digunakan. Selisih harga BBM dikalikan dengan jumlah liter kemudian dikurangkan atau ditambahkan dalam 5 biaya BBM terhadap tarif dengan acuan rasio yang sama.

3) Metode Tarif dengan tabel harga BBM

Metode tarif dengan table harga BBM merupakan metode yang dipakai dan disepakati antara principlel customer dengan transporternya dengan menggunakan Nilai tabel sebagai acuan kenaikan atau penurunan BBM sebagai berikut:

Tabel 1

Acuan Kenaikan atau penurunan BBM

\begin{tabular}{ccc}
\hline $\begin{array}{c}\text { Harga BBM dalam } \\
\text { Rp/Liter }\end{array}$ & Standard Tarif & $\begin{array}{c}\text { Contoh Tarif } \\
(\mathrm{Rp}):\end{array}$ \\
\hline $5000-6000$ & turun 6\% & $4,700,000.00$ \\
$6000-7000$ & $100 \%$ & $5,000,000.00$ \\
$7000-8000$ & Naik 6\% & $5,300,000.00$ \\
$8000-9000$ & Naik 12\% & $5,600,000.00$ \\
$9000-10000$ & Naik $18 \%$ & $5,900,000.00$ \\
\hline \hline
\end{tabular}

\section{Konsep Inventory Carrying Cost}

Inventory Carrying Cost merupakan dampak dari adanya biaya transportasi. Dapat digambarkan pula bahwa Inventory Carrying Cost merupakan biaya yang hilang karena barang 
tersebut belum terjual pada saat itu dikarenakan barang tersebut masih sedang diangkut oleh moda angkutannya.

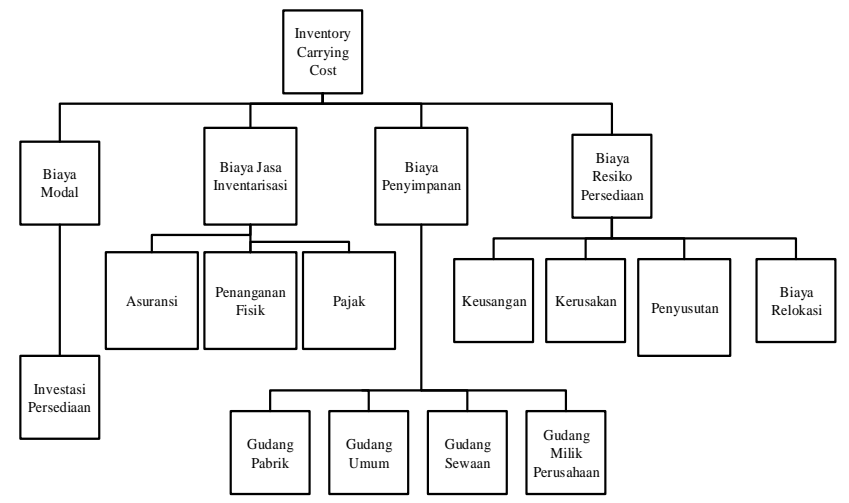

Gambar 2. Inventory Carrying Cost diagram

Menurut REM Associates tahun 1994 komponen dari Total Inventory Carrying Cost dapat diestimasikan dengan beberapa komponen biaya dari total biaya seperti pada tabel berikut [5] :

Tabel 2

Inventory Carrying Cost pada umumnya

\begin{tabular}{cc}
\hline \hline Biaya gudang & $2-5 \%$ \\
Asuransi & $1-3 \%$ \\
Pajak & $2-6 \%$ \\
Biaya uang & $6-12 \%$ \\
Kemunduran \& pencurian & $3-6 \%$ \\
Keusangan & $6-12 \%$ \\
Kontrol klerikal \& inventaris & $3-6 \%$ \\
Penanganan fisik & $2-5 \%$ \\
Total & $25 \%-55 \%$ \\
\hline \hline
\end{tabular}

\section{Metode Gravity}

Analisis gravitasi (gravity) banyak dipergunakan dalam perencanaan wilayah untuk memperkirakan daya Tarik suatu lokasi dibandingkan lokasi lain di sekitarnya. Dalam penelitian ini digunakan metode gravity untuk menentukan daerah hinterland pelabuhan Teluk Prigi [6].

Rumus Gravitasi secara umum adalah sebagai berikut :

$$
A_{i j}=\frac{k x P_{i} x P_{j}}{D_{i j}^{b}}
$$

Selanjutnya penggunaan rumus gravitasi tersebur dapat disederhanakan sebagai berikut [6]:

$$
A=\frac{P_{1} x P_{2}}{D^{b}}
$$

Keterangan :

$\mathrm{A}_{\mathrm{ij}}=$ Besarnya interaksi wilayah $\mathrm{i}$ dengan wilayah $\mathrm{j}$

$\mathrm{P}_{\mathrm{i}}=$ jumlah Muatan di wilayah i, dalam ton

$P_{j}=$ Jumlah muatan di wilayah $\mathrm{j}$,dalam ton

$\mathrm{D}_{\mathrm{ij}}=$ Jarak wilayah I dengan wilayah $\mathrm{j}$, dalam $\mathrm{km}$

$\mathrm{K}=$ Bilangan konstanta bedasarkan pengalaman

$\mathrm{B}=$ Pangkat dari $\mathrm{D}_{\mathrm{ij}}$, biasanya $\mathrm{b}=2$

\section{ANALISIS DAN PEMBAHASAN}

\section{A. Hinterland dan Muatan}

Pengiriman barang yang pada penelitian ini yaitu dari pelabuhan Tanjung Perak Surabaya dan (Pelabuhan Teluk prigi menuju daerah Jakarta (pelabuhan Tanjung Priok),
Kalimantan Selatan (pelabuhan Trisakti), Bali (pelabuhan Benoa) dan NTT(pelabuhan Tenau,Kupang) dengan asal muatan adalah barang dari hinterland di Jawa Timur

Daerah hinterland merupakan wilayah cakupan yang dilayani oleh pelabuhan. Di wilayah Jawa Timur terdapat 24 Kabupaten yang berpotensi menjadi hinterland pelabuhan teluk Prigi. Dengan menggunakan metode gravity diperoleh daerah hinterland beserta jarak dan waktu perjalanan menuju pelabuhan sebagai berikut:

$$
\text { Tabel } 3
$$

\begin{tabular}{|c|c|c|c|c|c|}
\hline No & $\begin{array}{l}\text { Daerah asal } \\
\text { (Hinterland) }\end{array}$ & $\begin{array}{c}\text { Jarak Ke } \\
\text { Pel. } \\
\text { T.Perak } \\
(\mathrm{KM})\end{array}$ & $\begin{array}{l}\text { Waktu } \\
\text { Tempuh } \\
\text { (Hari) }\end{array}$ & $\begin{array}{c}\text { Jarak Ke } \\
\text { Pel. } \\
\text { Teluk } \\
\text { Prigi } \\
(\mathrm{KM})\end{array}$ & $\begin{array}{l}\text { Waktu } \\
\text { Tempuh } \\
\text { (Hari) }\end{array}$ \\
\hline 1 & Magetan & 199 & 1 & 121 & 1 \\
\hline 2 & Ponorogo & 207 & 1 & 82,1 & 1 \\
\hline 3 & Nganjuk & 130 & 1 & 101 & 1 \\
\hline 4 & Blitar & 169 & 1 & 72,1 & 1 \\
\hline 5 & Tulungagung & 171 & 1 & 46,4 & 1 \\
\hline 6 & Kediri & 138 & 1 & 72,6 & 1 \\
\hline 7 & Trenggalek & 206 & 1 & 38,4 & 1 \\
\hline 8 & Pacitan & 279 & 2 & 143 & 1 \\
\hline
\end{tabular}

Daerah Hinterland

Pada penelitian ini muatan dari hinterland diproporsikan menurut jumlah muatan daerah dibandingkan dengan jumlah muatan bongkar muat Provinsi Jawa Timur ke daerah tujuan dikalikan $100 \%$ maka diketahui jumlah prosentase muatan setiap tujuan.

$$
\mathrm{P}=\frac{M s}{M p} \times 100 \%
$$

$\mathrm{P} \quad=$ proporsi muatan $(\%)$

Ms = Muatan Sesungguhnya (Eksisting) (ton)

$\mathrm{Mp}=$ Muatan bongkar muat Jawa Timur (ton)

Setelah diketahui prosentase muatan, maka prosentase muatan dikalikan dengan muatan sesungguhnya, maka akan didapatkan muatan sesungguhnya setiap daerah tujuan.

$$
M=P_{x} M s
$$

$\mathrm{M}=$ Muatan setiap daerah (ton)

Dari persamaan diatas maka diperoleh hasil perhitungan proporsi total muatan dari daerah hinterland menuju daerah tujuan yaitu sebagai berikut:

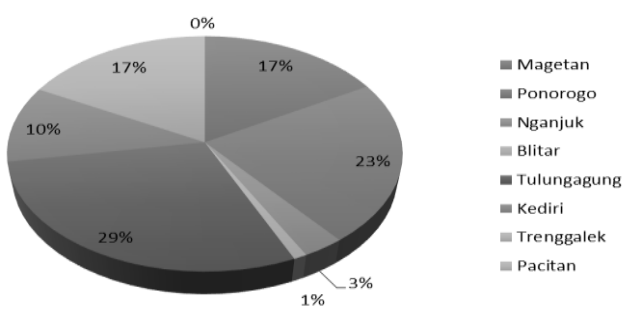

Gambar 3. Prosentase Muatan Setiap Daerah

Proporsi muatan Jawa Timur untuk Tujuan Jakarta, Kalimantan Selatan, Bali dan NTT adalah sebagai berikut: 


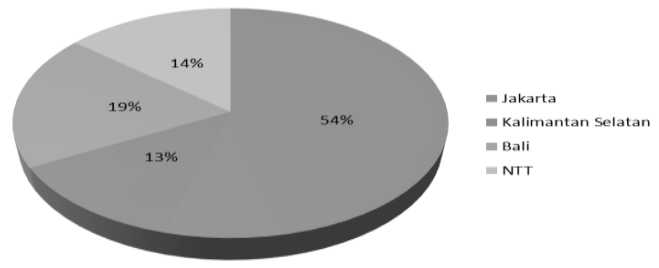

Gambar 4. Prosentase Muatan Jawa Timur

\section{B. Biaya Transportasi Laut}

Dalam perhitungan biaya transportasi Laut maka diperhitungkan jarak antar pelabuhan menggunakan aplikasi netpass distance sebagai berikut:

Tabel 4

Jarak Antar Pelabuhan

\begin{tabular}{|c|c|c|c|c|c|}
\hline \multirow{2}{*}{ No } & \multirow{2}{*}{$\begin{array}{l}\text { Pelabuhan } \\
\text { Tujuan }\end{array}$} & \multicolumn{2}{|c|}{$\begin{array}{c}\text { Jarak Berlayar } \\
(\mathrm{Km})\end{array}$} & \multicolumn{2}{|c|}{ Waktu Berlayarl (hari) } \\
\hline & & $\begin{array}{l}\text { Tanjung } \\
\text { Perak }\end{array}$ & $\begin{array}{l}\text { Teluk } \\
\text { Prigi }\end{array}$ & $\begin{array}{l}\text { Tanjun } \\
\text { g Perak }\end{array}$ & Teluk Prigi \\
\hline 1 & $\begin{array}{l}\text { Tanjung } \\
\text { Priok }\end{array}$ & 386 & 582 & 4 & 8 \\
\hline 2 & Trisakti & 269 & 667 & 4 & 8 \\
\hline 3 & Benoa & 294 & 312 & 4 & 4 \\
\hline 4 & Tenau & 760 & 805 & 8 & 10 \\
\hline
\end{tabular}

Kemudian dilakukan perhitungan total biaya tansportasi laut meliputi biaya capital, biaya operasinal, biaya perjalanan dan biaya bongkar muat barang sebagai berikut: Tabel 5

Total Biaya Transportasi laut

\begin{tabular}{|c|c|c|c|}
\hline NO & $\begin{array}{c}\text { RUTE } \\
\text { PELAYARAN }\end{array}$ & TOTAL COST (Rp) & $\begin{array}{l}\text { UNIT COST } \\
\text { (Rp/Ton) }\end{array}$ \\
\hline 1 & $\begin{array}{c}\text { TJ.PERAK- } \\
\text { TJ.PRIOK }\end{array}$ & $20.409 .228 .528,12$ & $1.687 .600,65$ \\
\hline 2 & $\begin{array}{l}\text { TJ.PERAK- } \\
\text { TRISAKTI }\end{array}$ & $20.221 .653 .544,37$ & $1.672 .090,42$ \\
\hline 3 & $\begin{array}{l}\text { TJ.PERAK- } \\
\text { BENOA }\end{array}$ & 20.227.275.090,24 & $1.672 .555,26$ \\
\hline 4 & $\begin{array}{c}\text { TJ.PERAK- } \\
\text { TENAU }\end{array}$ & $20.344 .860 .241,89$ & $1.682 .278,15$ \\
\hline 5 & $\begin{array}{l}\text { TELUK PRIGI- } \\
\text { TJ.PRIOK }\end{array}$ & $20.474 .227 .808,17$ & $1.692 .975,31$ \\
\hline 6 & $\begin{array}{l}\text { TELUK PRIGI- } \\
\text { TRISAKTI }\end{array}$ & $20.333 .936 .257,26$ & $1.681 .374,87$ \\
\hline 7 & $\begin{array}{l}\text { TELUK PRIGI- } \\
\text { BENOA }\end{array}$ & 20.245.107.967,95 & $1.674 .029,83$ \\
\hline 8 & $\begin{array}{c}\text { TELUK PRIGI- } \\
\text { TENAU }\end{array}$ & $20.379 .278 .670,17$ & $1.685 .124,15$ \\
\hline
\end{tabular}

\section{Biaya Transportasi Darat}

Perhitungan biaya transportasi darat untuk truk digunakan metode persen biaya terhadap tarif.Pada perhitungan ini harga BBM/ solar sebesar Rp. 6.700,- dengan rasio BBM terhadap tarif adalah $27.5 \%$ hingga 30\%. Sehingga diketahui biaya transportasi darat pada masing-masing daerah melalui pelabuhan Tanjung Perak ke daerah tujuan adalah sebagai berikut:

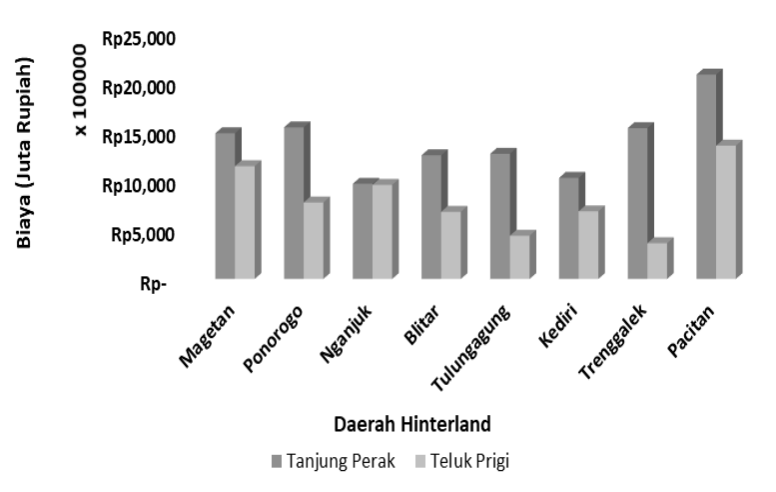

Gambar 5. Biaya Transportasi Darat dari hinterland Menuju pelabuhan

Sehingga diperoleh hasil perhitungan biaya transportasi darat pengangkutan muatan dari hinterland menuju pelabuhan Tanjung perak dan pelabuhan Teluk Prigi sebagai berikut:

Tabel 6

Unit Cost Biaya Transportasi Darat

\begin{tabular}{cccc}
\hline \hline & & & \multicolumn{2}{c}{ Unit Cost (Rp/Ton) } \\
NO & DAERAH ASAL & Tanjung Perak & Teluk Prigi \\
\hline 1 & Magetan & 122,219 & 94,582 \\
2 & Ponorogo & 127,133 & 64,175 \\
3 & Nganjuk & 79,842 & 78,948 \\
4 & Blitar & 103,794 & 6,358 \\
5 & Tulungagung & 105,023 & 36,269 \\
6 & Kediri & 84,755 & 56,749 \\
7 & Trenggalek & 126,518 & 30,016 \\
8 & Pacitan & 171,353 & 111,778 \\
\hline \hline
\end{tabular}

\section{Inventory carrying Cost}

Perhitungan inventory carrying cost yaitu total waktu perjalanan dikalikan dengan harga barang dan bunga bank selama satu hari.suku bunga bank yang digunakan $0.02 \%$ per hari. Sebelum dilakukan perhitungan inventory carrying cost maka dihitung jarak masing-masing hinterland menuju daerah tujuan sebagai berikut:

Tabel 7

Total Waktu Perjalanan Melalui Pelabuhan Tj.Perak

\begin{tabular}{|c|c|c|c|c|c|}
\hline \multirow{2}{*}{ No } & \multirow{2}{*}{ Daerah } & \multicolumn{4}{|c|}{ Melalui Pelabuhan Tanjung Perak (Hari) } \\
\hline & & Jakarta & Kalimantan & Bali & NTT \\
\hline 1 & Magetan & 28 & 36 & 38 & 47 \\
\hline 2 & Ponorogo & 28 & 36 & 38 & 47 \\
\hline 3 & Nganjuk & 28 & 36 & 38 & 47 \\
\hline 4 & Blitar & 28 & 36 & 38 & 47 \\
\hline 5 & $\begin{array}{c}\text { Tulungagun } \\
\mathrm{g}\end{array}$ & 28 & 36 & 38 & 47 \\
\hline 6 & Kediri & 28 & 36 & 38 & 47 \\
\hline 7 & Trenggalek & 28 & 36 & 38 & 47 \\
\hline 8 & Pacitan & 29 & 37 & 39 & 48 \\
\hline
\end{tabular}

Berikut waktu perjalanan dari daerah hinterland menuju daerah Jakarta, Kalimantan Selatan, Bali dan NTT melalui pelabuhan Teluk Prigi yaitu: 
Tabel 8

Total Waktu Perjalanan Melalui Pelabuhan Teluk Prigi

\begin{tabular}{llcccc}
\hline \hline No & \multicolumn{1}{c}{ Daerah } & \multicolumn{4}{c}{ Melalui Pelabuhan Teluk Prigi (Hari) } \\
& & Jakarta & Kalimantan & Bali & NTT \\
\hline 1 & Magetan & 38 & 46 & 43 & 49 \\
2 & Ponorogo & 38 & 46 & 43 & 49 \\
3 & Nganjuk & 38 & 46 & 43 & 49 \\
4 & Blitar & 38 & 46 & 43 & 49 \\
5 & Tulungagung & 38 & 46 & 43 & 49 \\
6 & Kediri & 38 & 46 & 43 & 49 \\
7 & Trenggalek & 38 & 46 & 43 & 49 \\
8 & Pacitan & 38 & 46 & 43 & 49 \\
\hline \hline
\end{tabular}

Dalam perhitungan inventory carryinng cost dikarenakan jenis muatan sangat beragam maka dilakukan kluster barang berdasarkan harga seperti pada tabel berikut:

$$
\text { Tabel } 9
$$

Kluster Harga Barang

\begin{tabular}{cc}
\multicolumn{2}{c}{ Kluster Harga Barang } \\
\hline \hline Harga \\
\hline Rendah & Rp.1-Rp.100,000 \\
Sedang & Rp.100,001 -Rp.500,000 \\
Tinggi & $>$ Rp. 500,000 \\
\hline \hline
\end{tabular}

Sehingga diperoleh proporsi barang berdasarkan harga sebagai berikut:

Tabel 10

Proporsi Barang Berdasarkan Harga

\begin{tabular}{cccccc}
\hline \hline No & Muatan & Jumlah & Total Muatan & Proporsi & Harga \\
\hline 1 & Rendah & 996,367 & $1,002,584$ & $99.38 \%$ & Rp54,607 \\
2 & Sedang & $6,091.64248$ & $1,002,584$ & $0.61 \%$ & Rp114,847 \\
3 & Tinggi & 126 & $1,002,584$ & $0.01 \%$ & Rp10,083 \\
\hline \hline
\end{tabular}

Setelah diketahui proporsi masing-masing harga barang maka selanjutnya dilakukan perhitungan inventory carrying cost sebagai berikut:

Tabel 10

unit cost dari inventory carrying cost muatan harga rendah

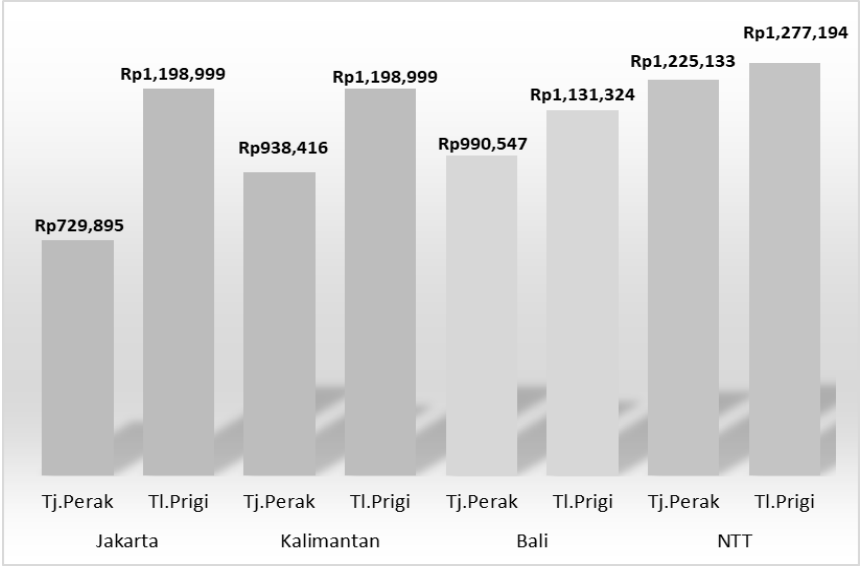

Tabel 11

Unit Cost dari Inventory Carrying Cost Muatan Harga Sedang

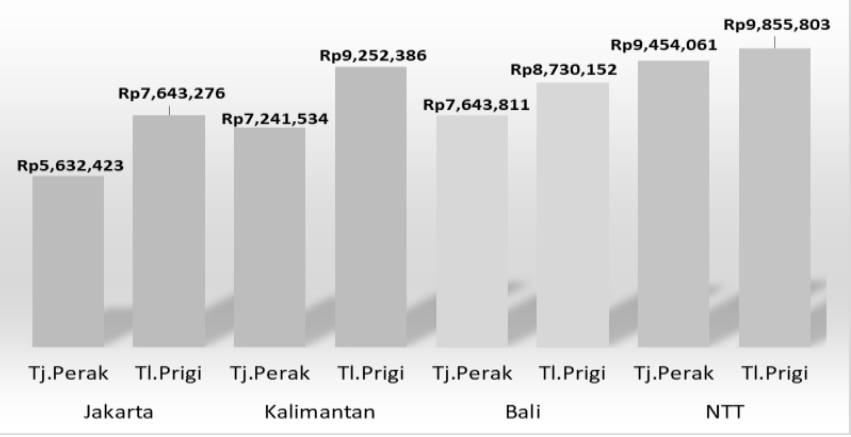

Tabel 12

Unit Cost dari Inventory Carrying Cost Muatan Harga Tinggi

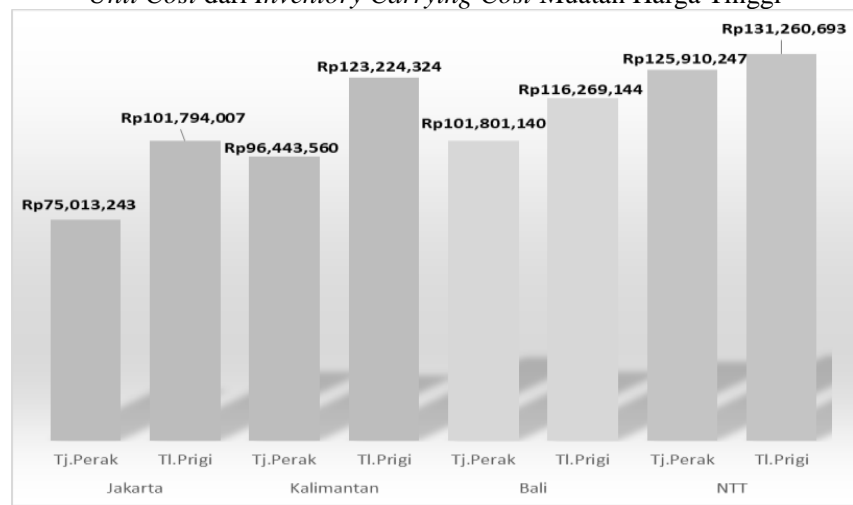

\section{E. Rekapitulasi Perhitungan Biaya}

Dalam rekapitulasi perhitungan biaya maka didapatkan hasil perhitungan sebagai berikut:
Tabel 13

Perbandingan Total biaya Transportasi

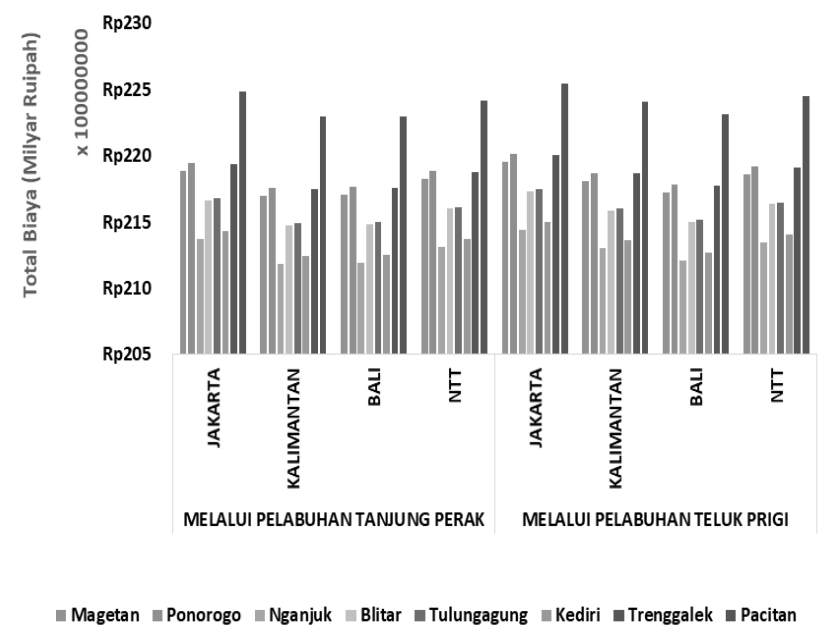

Dari tabel 13 diketahui biaya transportasi dari setiap daerah lebih rendah jika dikirimkan melalui pelabuhan Tanjung Perak Surabaya dibandingkan melalui pelabuhan Teluk Prigi.

Selanjutnya dilakukan rekapitulasi perhitungan dan perbandingan unit cost biaya transportasi dari daerah hinterland menuju pelabuhan sebagai berikut: 
Tabel 14

Unit Cost Biaya Transportasi

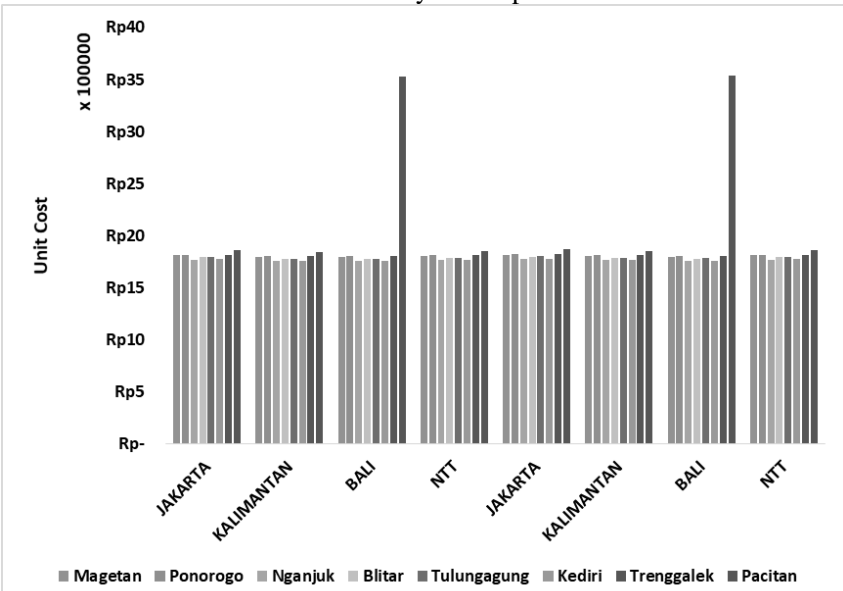

Dari dijelaskan bahwa unit cost muatan dari daerah hinterland kedaerah Jakarta, Kalimanta, Bali dan NTT lebih besar jika dilakukan melalui Pelabuhan Teluk Prigi. Diketahui unit cost muatan dari pacitan melalui Pelabuhan Tanjung Perak Surabaya yaitu sebesar Rp. 3.531.508,sedangkan unit cost muatan melalui pelabuhan Prigi yaitu Rp. 3.532.983,--

Selanjutnya dilakukan rekapitulais perhitungan inventory carryin cost muatan, sehingga diperoleh hasil perhitungan unit cost pada masing-masing kluster harga sebagai berikut: Tabel 15

Unit Cost dari Invnetory Carrying cost

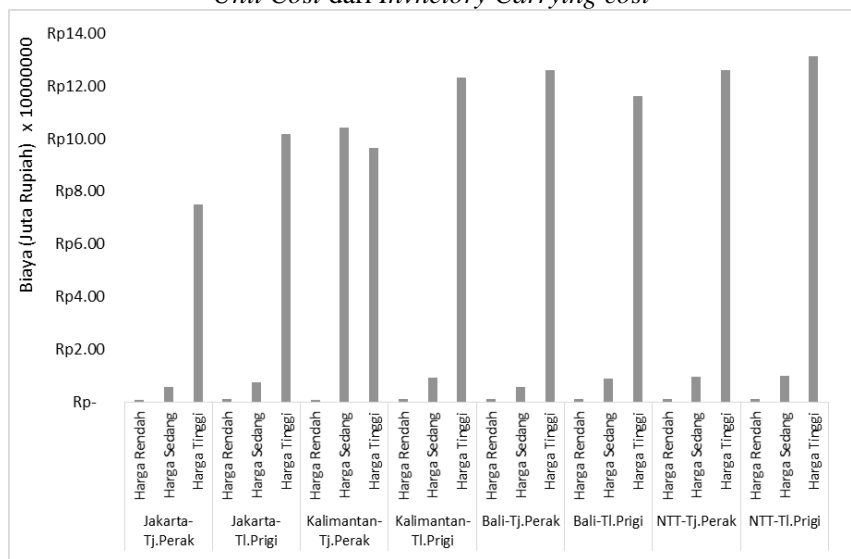

Dari hasil analisis diketahui bahwa unit cost dari inventory carrying cost muatan untuk tujuan Jakarta, Bali Banjarmasin dan NTT lebih tinggi jika melewati pelabuhan Teluk Prigi dibandingkan melalui pelabuhan Tanjung Perak.

\section{KESIMPULAN}

Dari hasil penelitian dan perhitungan yang telah dilakukan, maka diperoleh beberapa kesimpulan sebagai berikut:

1. Secara keseluruhan biaya transportasi muatan dari daerah hinterland menuju daerah Jakarta, Kalimantan, Bali, dan NTT lebih rendah jika muatan dikirimkan melalui Pelabuhan Tanjung Perak Surabaya dibandingkan Pelabuhan Teluk Prigi Trenggalek dengan selisih unit cost Rp. 5.375 ,- per ton untuk muatan tujuan Jakarta, Rp. 9.284,- per ton untuk muatan tujuan Kalimantan, Rp. 1.475,- per ton untuk muatan tujuan Bali dan Rp. 2.846,- per ton untuk muatan tujuan NTT.
2. Secara keseluruhan inventory carrying cost muatan dari daerah hinterland dengan tujuan Jakarta, Kalimantan, Bali, dan NTT lebih rendah jika muatan dikirimkan melalui pelabuhan Tanjung Perak Surabaya dibandingkan melalui Pelabuhan Teluk Prigi Trenggalek yaitu:

- Untuk muatan harga rendah selisih unit cost dari inventory carrying cost muatan adalah $0,3 \%$ untuk muatan dengan Tujuan Jakarta, 0,2\% untuk muatan tujuan Kalimanta, 0,1\% untuk muatan tujuan Bali dan $0,04 \%$ untuk muatan tujuan NTT.

- Untuk muatan harga sedang selisih unit cost dari inventory carrying cost muatan adalah $0,3 \%$ untuk muatan dengan Tujuan Jakarta, 0,2\% untuk muatan tujuan Kalimanta, 0,1\% untuk muatan tujuan Bali dan $0,04 \%$ untuk muatan tujuan NTT.

- Untuk muatan harga tinggi selisih unit cost dari inventory carrying cost muatan adalah $0,3 \%$ untuk muatan dengan Tujuan Jakarta, 0,2\% untuk muatan tujuan Kalimanta, 0,1\% untuk muatan tujuan Bali dan 0,02\%-0,04\% untuk muatan tujuan NTT.

\section{DAFTAR PUSTAKA}

B. J. Timur, Pertumbuhan Ekonomi Jawa Timur. Bappeda, 2012 B. P. J. Timur, Pendapatan Perkapita Daerah di Provinsi Jawa Timur. 2012.

N. W. Wergeland, Shipping. Netherland, 1997.

H. I. Nur, "Kajian Usulan Kebijakan Pendulum Nusantara Tinjauan Sektor Pelayaran dan Kepelabuhanan,” 2014.

R. Associates, "Methodology of Calculating Inventory Carrying Cost." REM Associates Management Consultants," 1994.

Daldjoeni, Teori Gravity. 2016. 